\title{
Effect of pure Aluminum in Reduction of Silica from Sediments in Iraqi- Tigris
}

\author{
Bariq A.H. Al-Qaisi ${ }^{a *}$ and Sami. I.J. Al-Rubaiey ${ }^{a}$ \\ Dept. Production Eng. \& Metallurgy, University of Technology, Baghdad, Iraq
}

\begin{abstract}
Article history:
\section{Keywords: \\ Tigris River \\ Sediments \\ Pyrometallurgy \\ Hydrometallurgy \\ Silic, and silicon}

A R T I CLE INFO

Received 03 April 2019

Received in revised form 15 May 2019

Accepted 19 May 2019

\begin{abstract}
A B S T R A C T
This work was carried out on sediments in the Iraqi- Tigris river within the city of Baghdad. Three locations were taken from the Tigris river. The first is at the entrance to Baghdad City (Al-Muthanna Bridge), the second is in central Baghdad (Adhamiya) and the third is at the end of Baghdad (Diyala Jisr). The specimens were taken from the banks of the Tigris river at 1.5 meters from the edge of the water and a depth of 2 meters. Sediments formed mainly from silica, with concentrations between $59-66 \%$. Therefore, the study focused on extracting the pure silicon element from these sediments. The extraction process of silicon from the sediments was performed in two stages. The first is pyrometallurgy stage, in which the reduction of silica was done by mixing pure aluminum powder with sediments at different mixing ratio (1:1, 1.5:1 and 2:1) sediments/aluminum and at temperatures $(900,950 \text { and } 1000)^{\circ} \mathrm{C}$. The second stage was hydrometallurgy (leaching process), this process was carried out by using different concentrations $(3,4$ and 5)M of sulfuric acid to obtain silicon element with purity $98.9 \%$. The results show that the efficiency of extraction silicon from sediments of the Tigris river is greater than $(88 \%)$.
\end{abstract}

\section{Introduction}

The sediments are formed on the banks of the rivers and at riverbed as a result of drift of the soil with the movement of water, in addition to the effect of streams and small rivers flowing into the main river [1].

The sediments are taken from the banks of Tigris river which contain various compounds such as $(\mathrm{SiO} 2, \mathrm{CaO}, \mathrm{MgO}, \mathrm{Fe} 2 \mathrm{O} 3, \mathrm{TiO} 2, \mathrm{Al} 2 \mathrm{O} 3$, $\mathrm{P} 2 \mathrm{O} 5$, and $\mathrm{K} 2 \mathrm{O}$ ) at different concentrations. The source of sediments in Tigris River come from several areas, The most important one as Anatolia Plateau in Turkey: Also Tigris tributaries continue as the source of sediments in the Tigris river in Iraqi territory such Khabur, Great zab, Little zab ,Diyala river and Adhaim River [1].
The Sediments vary in Tigris river depending on the quality of the water and affected by different pollutants and type of soil and effect of Dayala river on these sediments $[2,3,4]$.

The synthesis of high purity silicon from natural substances has been performed by several researchers, using metals like $\mathrm{Mg}, \mathrm{Ca}, \mathrm{Al}$ or $\mathrm{C}$ as reducing agents [5,6]. Sadique [7] extracted high purity silicon $(99.1 \%$ purity) from the waste of silica fume (SF). He reached to $99.1 \%$ Si by using Pyrometallurgical process . The best temperature for reduction was (750$850)^{\circ} \mathrm{C}$ at $2: 1$ mixing ratio of $\mathrm{Mg} / \mathrm{SF}$. Jehad \& Jasim [8] studied the extraction of silicon with a high purity of $99 \%$ by using Iraqi starting

* Corresponding author.

E-mail address: kaka2013331@gmail.com (Bariq A.H. Al-Qaisi) 
materials (quartzite rock, plant coal) via electric arc furnace at $1500{ }^{\circ} \mathrm{C}$. Mishra et al. [9] produced Polycrystalline silicon from amorphous silica obtained from rice-husk white ash by using calcium at the reduction temperature equaled to $720^{\circ} \mathrm{C}$. The final purity of silicon was $99.9 \%$ after acid leaching with concentrated HNO3 and HF . Onojah, A. [10] studied the extraction of silicon from rice husk ash and natural quartz by using magnesium powder however the two sources of silica gave silicon purities in the range of $97-98 \%$. This study focuses on extracting pure silicon element from Sediments in Iraqi-Tigris River which contain silica for percentage $(59-66) \%$

\section{Experimental work}

\subsection{Sampling preparations}

The specimens were taken from three locations at Tigris river in Baghdad City. The first is at the entrance to Baghdad City (Al-Muthanna Bridge), the second is in central Baghdad (Adhamiya) and the third is at the end of Baghdad (Diyala Jisr).

The specimens were taken from the banks of the Tigris river at $1.5 \mathrm{~m}$ from the edge of the water and a depth of $2 \mathrm{~m}$ at three different locations along the Tigris River within Baghdad city. which are;

- Al Muthanna Bridge

- Al-Adhamiyah

- Jisr Diyala

The samples were taken by $10 \mathrm{~kg}$ from each mentioned location, in depth of $2 \mathrm{~m}$. These samples were taken using steel- mold, The samples then dried at $100^{\circ} \mathrm{C}$ for $4 \mathrm{hrs}$. This process was achieved by using a bender oven.

\subsection{Chemical analysis}

Chemical analysis of the river-sediments was carried out by using X-Ray Fluorescence (XRF) at the University of Baghdad / Iraqi- German laboratory as shown in Tables $\mathbf{1 , 2}$ and 3.

Table 1. X-Ray Fluorescence (XRF) at the Al-Muthanna Bridge

\begin{tabular}{cc}
\hline Compounds & Concentration \% \\
\hline $\mathrm{SiO}_{2}$ & 59.974 \\
$\mathrm{CaO}$ & 20.421 \\
$\mathrm{Al}_{2} \mathrm{O}_{3}$ & 8.035 \\
$\mathrm{Fe}_{2} \mathrm{O}_{3}$ & 4.94 \\
$\mathrm{~K}_{2} \mathrm{O}$ & 1.447 \\
$\mathrm{P}_{2} \mathrm{O}_{5}$ & 0.702 \\
$\mathrm{MgO}$ & 3.255 \\
$\mathrm{TiO}_{2}$ & 0.739 \\
\hline
\end{tabular}

Table 2. X-Ray Fluorescence (XRF) at Al-Adhamiya Location

\begin{tabular}{cc}
\hline Compounds & Concentration \% \\
\hline $\mathrm{SiO}_{2}$ & 59.29 \\
$\mathrm{CaO}$ & 18.17 \\
$\mathrm{Al}_{2} \mathrm{O}_{3}$ & 8.739 \\
$\mathrm{Fe}_{2} \mathrm{O}_{3}$ & 5,848 \\
$\mathrm{~K}_{2} \mathrm{O}$ & 1.523 \\
$\mathrm{P}_{2} \mathrm{O}_{5}$ & 0.688 \\
$\mathrm{MgO}$ & 3.835 \\
$\mathrm{TiO}_{2}$ & 0.752 \\
Others & 0.165 \\
\hline
\end{tabular}

Table 3. X-Ray fluorescence (XRF) at Jisr Diyala Location

\begin{tabular}{cc}
\hline Compounds & Concentration\% \\
\hline $\mathrm{SiO}_{2}$ & $\mathbf{6 6 . 0 0 7}$ \\
$\mathrm{CaO}$ & $\mathbf{1 6 . 2 6}$ \\
$\mathrm{Al}_{2} \mathrm{O}_{3}$ & $\mathbf{7 . 7 0}$ \\
$\mathrm{Fe}_{2} \mathrm{O}_{3}$ & $\mathbf{4 . 2 4}$ \\
$\mathrm{K}_{2} \mathrm{O}$ & $\mathbf{1 . 4 0 0}$ \\
$\mathrm{P}_{2} \mathrm{O}_{5}$ & $\mathbf{0 . 7 0 2}$ \\
$\mathrm{MgO}$ & $\mathbf{2 . 5 4}$ \\
$\mathrm{TiO}_{2}$ & $\mathbf{0 . 6 6 2}$ \\
Other & $\mathbf{0 . 0 7 8}$ \\
\hline
\end{tabular}

\subsection{Grinding and Sieving Processes}

These processes were accomplished to obtain particles with a size equal to $63 \mu \mathrm{m}$ by using Ball mill machine for grinding time of $1 \mathrm{hr}$.The speed of the ball milling was $300 \mathrm{rpm}$. Auto sieve shaker device at a specified range $53-710 \mu \mathrm{m}$ was used for grinding process.

\subsection{Washing process (primary leaching)}

The samples are washing by using hydrochloric acid at $10 \%$ concentration for removal some metal oxides such as $(\mathrm{MgO}, \mathrm{CaO})$ and increases the silica ratio $[11,12]$. This process was done by a magnetic stirrer device for $80{ }^{\circ} \mathrm{C}$ at $2 \mathrm{hrs}$ with a rotation speed of 500rpm and solid-liquid ratios (14). After each experience, the sample was filtered and dried in an oven at $100{ }^{\circ} \mathrm{C}$ for $2 \mathrm{hr}$. The following equations illustrate the process of dissolving some of the impurities $[13,14]$.

$\mathrm{CaO}+2 \mathrm{HCl}=\mathrm{CaCl}_{2}+\mathrm{H}_{2} \mathrm{O}$

$\mathrm{MgO}+2 \mathrm{HCl}=\mathrm{MgCl}_{2}+\mathrm{H}_{2} \mathrm{O}$

\subsection{Mixing and Pressing Processes}

Different ratio of $\mathrm{Al} /$ Sediments were used. These ratios are $(1: 1,1.5: 1$, $2: 1)$ the specimens were compressed using compression a die with a diameter of $3 \mathrm{~cm}$, the applied load was 20 ton for $1 \mathrm{~min}$.

\subsection{Reduction Process}

The reduction process was carried out in carbolite furnace (type cwf $12 / 13$, England) at temperatures $900,950,1000^{\circ} \mathrm{C}$ for $2 \mathrm{hrs}$, The specimens were tightly covered in steel crucible for dimensions $(11 \mathrm{~cm}$ diameter, and 15 $\mathrm{cm}$ length ) to full the crucible. The cover was supplied with value allow for following for argon gas flow. All specimens were tested by atomic absorption spectrometry, X-ray Diffraction Analysis test was done onetime for each reduction temperature.

\subsection{Leaching process}

The leaching process was done to remove impurities in the reduction process by using sulfuric acid at 3,4 and $5 \mathrm{M}$ and leaching temperature $100{ }^{\circ} \mathrm{C}$ for $4 \mathrm{hrs}$ and solid to liquid ratio of 1:6 via using Heating mantle device. The insoluble residue was separated from the solution by vacuum pump using filtration paper. Then the filtered cake was washed with distilled water several times and then dried in an oven at $100{ }^{\circ} \mathrm{C}$ for $1 \mathrm{hr}$.

\subsection{X-ray Diffraction Analysis}

To identify the formed compounds after reduction X-ray test was done on machine BRUKER. The test was accomplished under the following parameters: voltage $40 \mathrm{kV}$, current $30 \mathrm{~mA}, 1.540 \mathrm{~A}^{\circ}$ and scan rate 5-10 ${ }^{\circ} \mathrm{deg} / \mathrm{min}$. The test was done at geological department, college of sciences, University of Baghdad. 


\subsection{X-ray fluorescence analysis}

The purity of extracted silicon powder was tested by using X-ray fluorescence-XRF a type (AMETEK 2010 Germany). The analysis was conducted at the place mentioned above.

\section{Results and discussion}

\subsection{Washing process (Primary leaching)}

Tables 4, 5 and 6 show the increase of silica percentage in samples and decrease the percentage of other compounds after Primary leaching process according to X-ray fluorescence analysis compared with Tables 1, 2 and 3.

Table 4. X-Ray Fluorescence (XRF) at the Al-Muthanna Bridge location

\begin{tabular}{cc}
\hline Compounds & Concentration \% \\
\hline $\mathrm{SiO}_{2}$ & 70.132 \\
$\mathrm{CaO}$ & 13.251 \\
$\mathrm{Al}_{2} \mathrm{O}_{3}$ & 9.522 \\
$\mathrm{Fe}_{2} \mathrm{O}_{3}$ & 2.651 \\
$\mathrm{~K}_{2} \mathrm{O}$ & 0.923 \\
$\mathrm{P}_{2} \mathrm{O}_{5}$ & 0.632 \\
$\mathrm{MgO}$ & 1.554 \\
$\mathrm{TiO}_{2}$ & 0.519 \\
$\mathrm{Other}$ & 0.816 \\
\hline
\end{tabular}

Table 5. X-Ray Fluorescence (XRF) at the Al-Adhamiyah Location

\begin{tabular}{cc}
\hline Compounds & Concentration \% \\
\hline $\mathrm{SiO}_{2}$ & 68.241 \\
$\mathrm{CaO}$ & 11.216 \\
$\mathrm{Al}_{2} \mathrm{O}_{3}$ & 11.631 \\
$\mathrm{Fe}_{2} \mathrm{O}_{3}$ & 3.642 \\
$\mathrm{~K}_{2} \mathrm{O}$ & 0.989 \\
$\mathrm{P}_{2} \mathrm{O}_{5}$ & 0.423 \\
$\mathrm{MgO}$ & 2.415 \\
$\mathrm{TiO}_{2}$ & 0.514 \\
Others & 0.929 \\
\hline
\end{tabular}

Table 6. X-Ray Fluorescence (XRF) at the Jisr Diyala Location

\begin{tabular}{cc}
\hline Compounds & Concentration \% \\
\hline $\mathrm{SiO}_{2}$ & 76.500 \\
$\mathrm{CaO}$ & 8.800 \\
$\mathrm{Al}_{2} \mathrm{O}_{3}$ & 10.415 \\
$\mathrm{Fe}_{2} \mathrm{O}_{3}$ & 2.145 \\
$\mathrm{~K}_{2} \mathrm{O}$ & 0.478 \\
$\mathrm{P}_{2} \mathrm{O}_{5}$ & 0.315 \\
$\mathrm{MgO}$ & 0.918 \\
$\mathrm{TiO}_{2}$ & 0.211 \\
Other & 0.218 \\
\hline
\end{tabular}

\subsection{Reduction Process}

The reduction process by mixing aluminum powder with sediments was carried out to obtain the silicon element from sediments in the Tigris river. The compounds present in the products at different temperature were $\mathrm{Si}$ and some traces like $\mathrm{Al} 2 \mathrm{O} 3$, and $\mathrm{Al}$ non-react. In addition to the small amount of non-reacted silica as shown in Tables 7, 8 and 9.The mixing aluminum powder with silica in the reduction process, $\mathrm{Al}$ reacts with silica to produce directly $\mathrm{Si}$ element and alumina ( $\mathrm{Al} 2 \mathrm{O} 3$ ), because the aluminum element is more active metal than silicon, according to the following reaction(3)[12,13]. The corresponding X-Ray diffraction analysis (XRD) was shown in Fig. 1.

$$
3 \mathrm{SiO}_{2}+4 \mathrm{Al}=2 \mathrm{Al}_{2} \mathrm{O}_{3}+3 \mathrm{Si}
$$

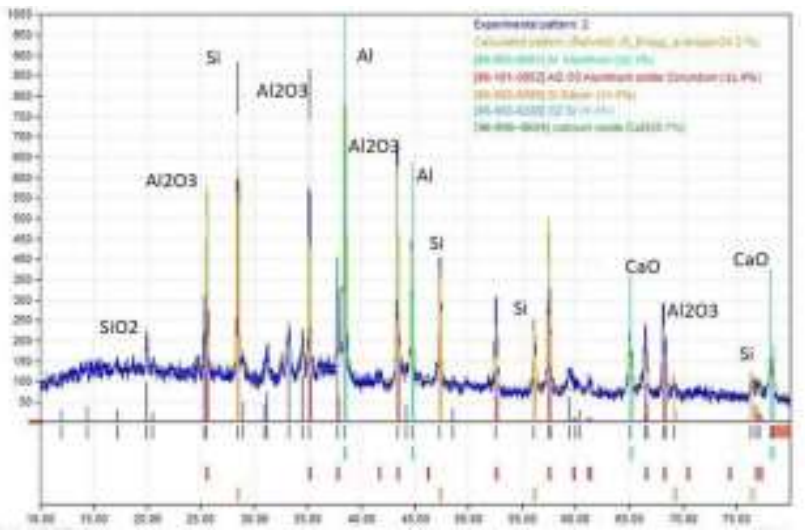

Figure 1. XRD pattern of reduction products at $1000^{\circ} \mathrm{C}$ and ratio of Al/sediments 1:1

Table 7. Effect of $\mathrm{Al} / \mathrm{sediments} \mathrm{ratio} \mathrm{in} \mathrm{reduction} \mathrm{process} \mathrm{at} \mathrm{different}$ temperature at the $\mathrm{Al}$ Muthanna Bridge location

\begin{tabular}{cccccccc}
\hline Al/Sediments & $\begin{array}{c}\text { Temperature } \\
\mathbf{C}^{\circ}\end{array}$ & $\begin{array}{c}\mathbf{S i} \\
\mathbf{\%}\end{array}$ & $\begin{array}{c}\mathbf{S i O} \\
{ }_{\mathbf{2}} \%\end{array}$ & $\mathbf{A l} \mathbf{\%}$ & $\begin{array}{c}\mathbf{A l}_{\mathbf{2}} \mathbf{O}_{\mathbf{3}} \\
\mathbf{\%}\end{array}$ & $\begin{array}{c}\mathbf{C a O} \\
\mathbf{\%}\end{array}$ & $\begin{array}{c}\text { Others } \\
\mathbf{\%}\end{array}$ \\
\hline $1: 1$ & 900 & 18.2 & 0.9 & 32.5 & 42.2 & 5.3 & 0.9 \\
$1: 1$ & 950 & 20.9 & 0.7 & 31.5 & 40.2 & 6.1 & 0.6 \\
$1: 1$ & 1000 & 24.8 & 0.4 & 38.1 & 32.9 & 3.1 & 0.7 \\
$1.5: 1$ & 900 & 13.5 & 2.7 & 32.05 & 43.5 & 7.3 & 0.9 \\
$1.5: 1$ & 950 & 14.9 & 1.5 & 35.9 & 44.1 & 7.1 & 1.1 \\
$1.5: 1$ & 1000 & 16.1 & 1.2 & 30.6 & 43.1 & 6.8 & 2.2 \\
$2: 1$ & 900 & 11.2 & 3.2 & 34.4 & 40.2 & 9.2 & 1.8 \\
$2: 1$ & 950 & 13.4 & 2.7 & 33.1 & 41.8 & 7.8 & 1.2 \\
$2: 1$ & 1000 & 13.7 & 1.7 & 40.5 & 38.1 & 5.4 & 0.6 \\
\hline
\end{tabular}

Table 8. Effect of $\mathrm{Al} /$ sediments ratio in reduction process at different temperature at the Al-Adhamiyah Location

\begin{tabular}{cccccccc}
\hline Al/Sediments & $\begin{array}{c}\text { Temperatue } \\
\mathbf{C}^{\circ}\end{array}$ & $\begin{array}{c}\mathbf{S i} \\
\mathbf{\%}\end{array}$ & $\begin{array}{c}\mathbf{S i O} \\
\mathbf{\%}\end{array}$ & $\begin{array}{c}\mathbf{A l} \\
\mathbf{\%}\end{array}$ & $\begin{array}{c}\mathbf{A l}_{\mathbf{2}} \mathbf{O}_{\mathbf{3}} \\
\mathbf{\%}\end{array}$ & $\begin{array}{c}\mathbf{C a O} \\
\mathbf{\%}\end{array}$ & Other\% \\
\hline $1: 1$ & 900 & 20.7 & 1.2 & 31.2 & 41.9 & 4.1 & 0.9 \\
$1: 1$ & 950 & 22.1 & 0.8 & 35.6 & 38.5 & 2.4 & 0.6 \\
$1: 1$ & 1000 & 25.3 & 1.9 & 29.1 & 38.9 & 3.8 & 1 \\
$1.5: 1$ & 900 & 16.4 & 1.6 & 38.3 & 39.6 & 3.2 & 0.9 \\
$1.5: 1$ & 950 & 14.8 & 1.5 & 32.6 & 46.8 & 2.7 & 1.6 \\
$1.5: 1$ & 1000 & 18.2 & 0.9 & 35.1 & 40.3 & 4.1 & 1.4 \\
$2: 1$ & 900 & 14.1 & 2.7 & 35.3 & 37.6 & 7.9 & 2.4 \\
$2: 1$ & 950 & 15.3 & 2.9 & 38.1 & 40.1 & 3.1 & 0.5 \\
$2: 1$ & 1000 & 15.6 & 2.4 & 37.4 & 38.2 & 4.9 & 1.5 \\
\hline
\end{tabular}

Table 9. Effect of Al/sediments ratio in reduction process at different temperature at the Jisr Diyala Location

\begin{tabular}{cccccccc}
\hline Al/Sediment & $\begin{array}{c}\text { Temperature } \\
\mathbf{C}^{\circ}\end{array}$ & $\begin{array}{c}\mathbf{S i} \\
\mathbf{\%}\end{array}$ & $\begin{array}{c}\mathbf{S i O}_{\mathbf{2}} \\
\mathbf{\%}\end{array}$ & $\begin{array}{c}\mathbf{A l} \\
\mathbf{\%}\end{array}$ & $\begin{array}{c}\mathbf{A l}_{\mathbf{2}} \mathbf{O}_{3} \\
\mathbf{\%}\end{array}$ & $\begin{array}{c}\mathbf{C a O} \\
\boldsymbol{\%}\end{array}$ & $\begin{array}{c}\text { Other } \\
\boldsymbol{\%}\end{array}$ \\
\hline $1: 1$ & 900 & 19.6 & 1.6 & 35.3 & 36.1 & 5.5 & 1.9 \\
$1: 1$ & 950 & 23.4 & 1.2 & 33.4 & 32.6 & 6.8 & 2.6 \\
$1: 1$ & 1000 & 26.1 & 2.4 & 26.9 & 36.8 & 6.1 & 1.7 \\
$1.5: 1$ & 900 & 15.1 & 2.1 & 31.2 & 40.6 & 8.2 & 2.9 \\
$1.5: 1$ & 950 & 16.8 & 1.5 & 35.7 & 37.8 & 6.5 & 1.7 \\
$1.5: 1$ & 1000 & 17.2 & 1.1 & 30.3 & 43.7 & 6.4 & 1.3 \\
$2: 1$ & 900 & 12.5 & 1.8 & 31.1 & 43.5 & 8.3 & 2.8 \\
$2: 1$ & 950 & 13.7 & 0.8 & 35.9 & 46.9 & 9.2 & 1.8 \\
$2: 1$ & 1000 & 13.5 & 1.3 & 36.4 & 39.5 & 7.9 & 1.4 \\
\hline
\end{tabular}




\section{A. Effect of $\mathrm{Al} /$ sediments ratio in the reduction process at different temperature:}

Tables 7,8 and 9 show the amount of $\mathrm{Al}$ powder added to sediments at referent mixing ratio 2:1, 1.5:1 and 1:1 and different temperature 900, 950, $1000{ }^{\circ} \mathrm{C}$. The Tables show that the amount of $\mathrm{Al}$ addition have a large effect on the reduction of silica Located in sediments. It had been shown that at $1000{ }^{\circ} \mathrm{C}$ using ratio $1: 1 \mathrm{Al} /$ Sediments, $\mathrm{Si}$ appears very high amount in three locations $\left(24.8,25.3\right.$, and 26.1) \%, whereas at $1000{ }^{\circ} \mathrm{C}$ ratio with a $2: 1$ appears small amount in three locations $(13.7,15.6$, and 13.5$) \%$. As a result of atomic absorption spectrometry and XRD analysis the percentage of extracted Silicon increase when mixing ratio decrease into 1:1 at constant temperature $1000{ }^{\circ} \mathrm{C}[7,15]$.

Sadique[7]:explain when mixing aluminum or magnesium powder with silica in the reduction process, $\mathrm{Al}$ or $\mathrm{Mg}$ can react with Silica to produce $\mathrm{Si}$ element and alumina compound (A12O3), because these elements are more active metal than silicon in ellingham diagram $(\Delta \mathrm{G}$ of aluminum or magnesium $\geq \Delta \mathrm{G}$ of silicon). Sadique extracted high purity silicon $(99.1 \%$ purity) from the waste of silica fume (SF) by using magnesium element to reduction of silica $(\mathrm{SiO} 2)$.

Figure (2) shows $\mathrm{Si}$ content as a function of $\mathrm{Al} /$ sediments. The maximum amount of $\mathrm{Si}$ is achieved at mixing ratio1:1. While the $\mathrm{Si}$ yield decreases at mixing ratio $2: 1$ because of non-reaction all silica $(\mathrm{SiO} 2)$ with $\mathrm{Al}$ powder.

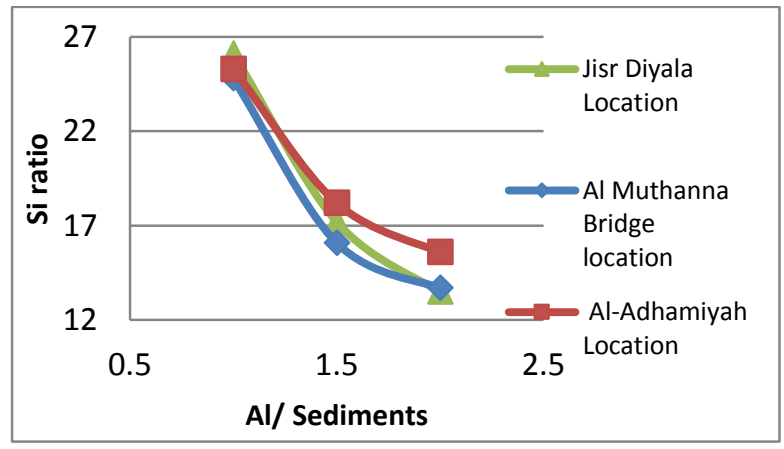

Figure 2. Shows the effect of $\mathrm{Al} / \mathrm{sediments}$ ratio on the silicon yield at three different locations.

\section{B. Effect of temperature in the reduction process:}

As shown in Tables 7, 8, and 9 that the effect of the temperature on the reduction process of $\mathrm{SiO} 2$ at a constant ratio of $\mathrm{Al} / \mathrm{SiO} 2$ (1:1). According to atomic absorption spectrometry and XRD analysis at $900^{\circ} \mathrm{C}$ appears silicon amount in three locations (19.6, 20.7, and 19.6). Whereas at high temperature of $1000^{\circ} \mathrm{C}$ the silicon amount increases (24.8, 25.3, and 26.1). As a result of atomic absorption spectrometer, the amount of $\mathrm{Si}$ increases when the temperature increases into $1000^{\circ} \mathrm{C}$ at constant mixing ratio $(1: 1)[7]$.

Figure 3. shows $\mathrm{Si}$ content as a function of temperature. The maximum amount of $\mathrm{Si}$ is achieved $1000{ }^{\circ} \mathrm{C}$. While the Si yield decrease at $900{ }^{\circ} \mathrm{C}$

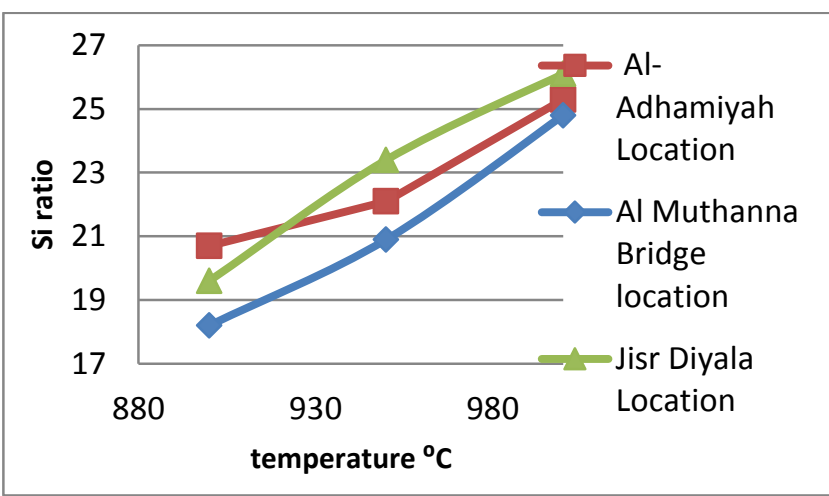

Figure 3. Shows the effect of temperature on silicon percentage at three different locations.

\subsection{Evaluation of silicon amount production}

The extraction of silicon process was evaluated since the main purpose of the reduction experiments is to achieve the highest amount of $\mathrm{Si}$ with high purity. The best condition for this process to obtain the maximum amount of $\mathrm{Si} 26.1 \%$ with high purity $98.9 \%$ is achieved at the $\mathrm{Al} /$ sediments ratio of $1: 1$ at $1000^{\circ} \mathrm{C}$.

\subsection{Hydrometallurgical Process}

Hydrometallurgy (leaching process) is a method for obtaining metals from their ores via using different solutions. the Pyrometallurgical process for extraction of silicon which was made at different conditions led to the production of various compounds in the reduction process such A12O3. For the purification of the Produced silicon, the leaching processes were used. Table (10) shows the purification of silicon produced an effect of sulfuric acid on dissolving impurities in the samples and figure (4) shows the EDX spectra of the silicon powder. Angus L. Daniels [16] and Paween Numluk [17] explained that the aluminum oxide (alumina) react with sulfuric acid at different concentration (3-5)M and forming aluminum sulfate according to following equation(5) at $100{ }^{\circ} \mathrm{C}$ for $4 \mathrm{hrs}$, The efficiency of silicon extracted from sediments of Tigris river is greater than (88\%).

$\mathrm{Al}_{2} \mathrm{O}_{3} \mathrm{H}_{2} \mathrm{O}+3 \mathrm{H}_{2} \mathrm{SO}_{4}=\mathrm{Al}_{2}\left(\mathrm{SO}_{4}\right)_{3}+6 \mathrm{H}_{2} \mathrm{O}$

Table 10. XRF analysis of purification of silicon when temperature $=100^{\circ} \mathrm{C}$, and time $=4 \mathrm{hHr}$

\begin{tabular}{ccccc}
\hline Samples & $\begin{array}{c}\text { Concentration } \\
\mathbf{M}\end{array}$ & $\mathbf{S i} \%$ & $\mathbf{S i O}_{\mathbf{2}} \%$ & $\mathbf{A l}_{\mathbf{2}} \mathbf{O}_{\mathbf{3}} \%$ \\
\hline Al-Muthanna & 3 & 95.98 & 0.3 & 3.72 \\
Bridge & 4 & 98.9 & 0.3 & 0.8 \\
& 5 & 93.24 & 0.4 & 6.36 \\
Adhamiyah & 3 & 96.43 & 1.4 & 2.17 \\
& 4 & 98.4 & 1.5 & 0.1 \\
\multirow{3}{*}{ Jisr Diyala } & 5 & 92.76 & 1.8 & 5.44 \\
& 3 & 96.92 & 2 & 1.08 \\
& 4 & 97.3 & 1.9 & 0.8 \\
& 5 & 93.65 & 2.1 & 4.25 \\
\hline
\end{tabular}




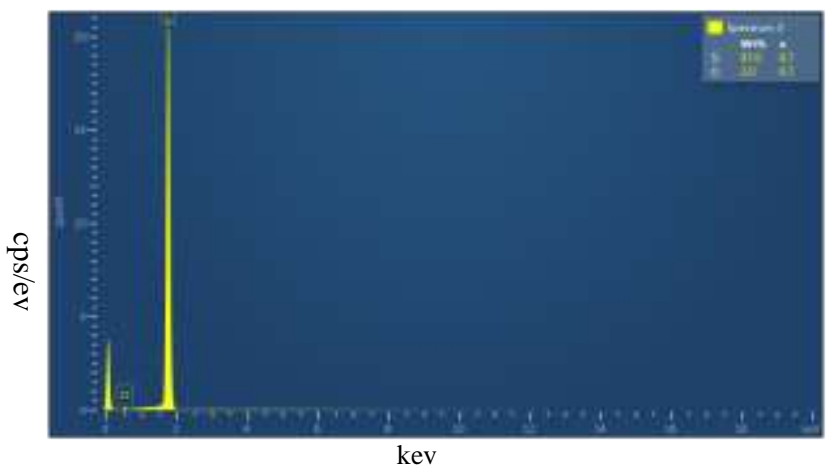

Figure 4. EDX spectra of the as-produced silicon

The SEM micrograph of the silicon powder as shown in Fig. 5. and it can be seen that the shape of particles is random and different size for $4 \mathrm{hrs}$ of leaching time, $100{ }^{\circ} \mathrm{C}$ of temperature and $(4 \mathrm{M})$ concentration of sulfuric acid.

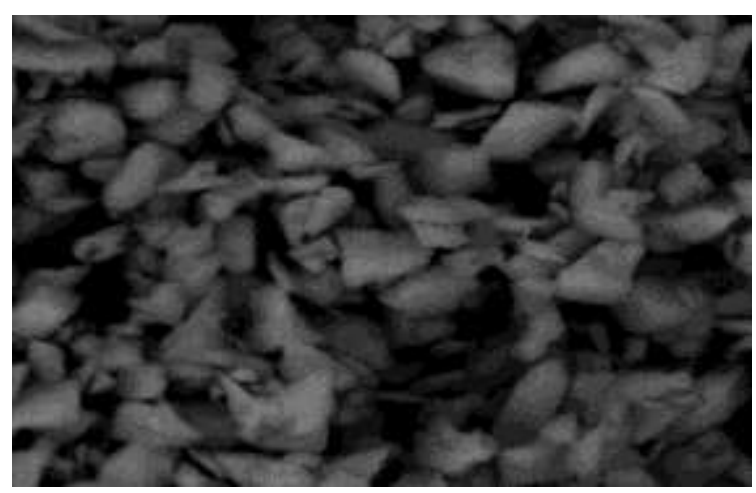

Figure 5. The SEM micrograph of as-produced silicon

The particle size distributions of silicon powder can be seen in Fig. 6. shows that approximately $90 \%$ volume of the produced silicon is $\leq 66 \mu \mathrm{m}$, $50 \%$ of the produced silicon volume $\leq 22 \mu \mathrm{m}$ and $10 \%$ volume of the produced silicon is $\leq 5 \mu \mathrm{m}$.

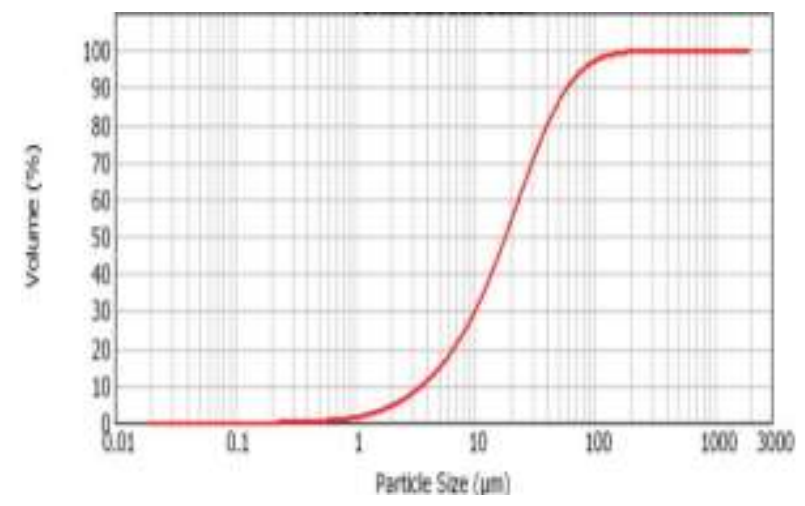

Figure 6. The particle size distribution of as-produced silicon

\section{Conclusions}

- Pure silicon $(98,9 \%)$ has been successfully produced from sediments of Tigris river by pyrometallurgy and hydrometallurgy processes
- The reduction process was carried out with attrition of aluminum powder $(63 \mu \mathrm{m}$ particle size) at different ratio ( $2 ; 1$, $1.5 ; 1$ and $1 ; 1)$ the best results obtained at ratio $1 ; 1$. The effect of $\mathrm{Al}$ powder is to decrease the reduction temperature of silica

- The leaching process carried out by using 4M H2SO4 to remove impurities such (Al2O3).

- The best reduction temperature was found at (1:1) mixing ratio of $\mathrm{Al} /$ Sediments was $1000^{\circ} \mathrm{C}$.

- The efficiency of silicon extracted from sediments of Tigris river is greater than $(88 \%)$

\section{REFERENCES}

[1] Al-Bassam, K.S. and Al-Mukhtar, L.E.,. Heavy minerals in sediments of the Euphrates River. Iraqi Bulletin of geology and mining, 4(1) (2008) p. $29-41$.

[2] Abdul-Hameed M. J. Al-Obaidy, Zahraa Zahraw Al-Janabi, Abdul-Rahman Al- Kubaisi, Distribution of Some Heavy Metals in Tigris River middle of Iraq, 11(2) (2014).

[3] Luma abdalalah skben Al-abadi, The relative distribution of mica minerals in sand fractions and different soil depths, AlQadisiyah Journal for Engineering Sciences, 14(4) (2008) p19.

[4] Philip, G., Mineralogy of Recent sediments of Tigris and Euphrates River and some older detrital deposits Jour. Sed. Pet. 38 (1968) p. $35-44$.

[5] Nazma and M. Akhter, X-Ray diffraction analysis of silicon prepared from rice husk ash, J. Mater. Sci. 23, 23792381 (1998).

[6] L. P. Hunt, J. P. Dismukes, J. A. Amick, A. Schei and K. Larsen, Rice hulls as a raw material for producing silicon, Journal of the Electrochemical Society, 131 (1984) P.16831686.

[7] S. Elius Sadique, Production and Purification of Silicon by Magnesiothermic Reduction of Silica Fume, Copyright by Sarder Elius Sadique, (2010).

[8] Jehad. Abed Taies \&amp; Jasim H. Hassen, Production of Silicon Metal From Iraqi Sand ,journal of Baghdad for science , 11(1) (2014).

[9] Mishra P., Chakraverty A. and Banerjee H.D. Production and purification of silicon by calcium reduction of rice-husk white ash. Journal of Materials Science, 20 (1985) P.4387-4391.

[10] Onojah, A., Amah, A. N. and Ayomanor, B. O, Comparative studies of silicon from rice husk ash and natural quartz, American Journal of Scientific and Industrial Research, 3(3) (2012) p.146-149.

[11] Daroon H. Khorsheed, Abbas R. Ali , Heavy Minerals Distribution in the Recent Stream Sediments of Diyala River Basin/ Northeastern IRAQ, Kirkuk University Journal /Scientific Studies, 10(4) (2015) p.415-438

[12] Abdul Salam Mehdi Salih, Study of morphological aspects and variation of clay minerals in the recent alluvial sediments of Tigres River in Sharqat area, Tikrit Journal of Pure Science, 15(1) (2009).

[13] Lide 'David. CRC Handbook of Chemistry and Physics, (2000).

[14] Perry ،R.؛ Green D.؛ Maloney J. Perry's Chemical Engineers' Handbook, (1984).

[15] Takeshi Okutami., Utilization of Silica in Rice Hulls as Raw Materials for Silicon Semiconductors , Journal of Metals, Materials and Minerals, 19 (2) (2009) pp.51-59.

[16] Angus L. Daniels, Edison Muzenda, Recovery of Aluminium Oxide from Flint Clay through $\mathrm{H} 2 \mathrm{SO} 4$ Leaching, Proceedings of the World Congress on Engineering, 3 (2012) p1-3, 3p.

[17] Paweena Numluk and Aphiruk Chaisena, Sulfuric Acid and Ammonium Sulfate Leaching of Alumina from Lampang Clay, E-Journal of Chemistry, 9(3) (2012) p. 1364-1372 